\title{
Novel Coronavirus (COVID-19) Treatment Options
}

Mujib Ullah*

Interventional Regenerative Medicine and Imaging Lab, Department of Radiology, School of Medicine, Stanford University, California, USA.

\section{* Corresponding author}

\section{Mujib Ullah}

Stanford University

School of Medicine

California USA

Email: ullah@stanford.edu

\begin{abstract}
Coronavirus also called SARS-COV-2 showed highly pathogenic, caused severe or even life-threatening diseases, and still transmitted from person-to-person. Given fast evolution of the COVID-19 outbreak, world health organization declared its outbreak as pandemic. Until now, no drugs or biologics have been proven to be effective for the prevention or treatment of COVID-19. Mainstream medicine has little in its arsenal for viral diseases. Some promising agents are selectively RNA inhibitors, an antimalarial agent, an HIV protease inhibitor, and an influenza viral neuraminidase inhibitor, which showed good clinical efficacy in treating COVID-19.
\end{abstract}

Key words: RNA virus, Coronavirus, COVID-19, World Pandemic. 


\section{Short Review}

Coronavirus are enveloped, positive-stranded RNA viruses with nucleocapsid ${ }^{1-3}$. So far it appears that COVID-19 predominantly affects the lower respiratory tract leading to break down of the lung cells, with infiltration of fluid, hemorrhage, and inflammatory cells into the alveolar space that manifest the disease further 2,4-6. As a result of inflammatory/repair process, these areas develop pneumonia ${ }^{7}$. Coronaviruses uses angiotensin-converting enzyme 2 (ACE2) to target cells on the epithelium of the lungs, intestine, and blood vessels $5,8,9$.

Many viruses require surface proteins for cell fusion and entry ${ }^{8,10}$. Coronavirus has three major proteins, named, spike $(S)$ protein, envelope $(E)$ protein, nucleocapsid protein $(N)$ and membrane $(\mathrm{M})$ protein ${ }^{1,2,8,9}$. The $\mathrm{N}$ is a structural protein that binds to the coronavirus RNA genome, thus creating a shell around the nucleic materials ${ }^{2,8,9}$. The $S$ protein is responsible for host infection by facilitating the attachment and enables viral entry into the host cell ${ }^{2,9,10}$. ACE2 is an endogenous membrane protein that facilitates COVID-19 infection (Figure: 1) ${ }^{8,10}$.

There is currently no vaccine or treatment for coronavirus disease ${ }^{11,12}$. Artificial intelligence has improved diagnosis and treatment outcomes in cancer patients and can be used for the clinical diagnosis of the COVID-19 ${ }^{13-16}$. The pandemic of coronavirus disease has accelerated the race for development of vaccines and other therapeutic options ${ }^{11,12}$. Chloroquine, a drug used to treat malaria and arthritis, was approved by the US Food and Drug Administration to be tested as a treatment for coronavirus ${ }^{12}$. Chloroquine is being tested in various clinical trials, while other antivirals drugs are also planned to be fast-tracked for testing for coronavirus such as Favilavir and others as mentioned in table $1^{2,11,12,17-19}$. There is no specific medicine to prevent or treat coronavirus disease. Listed drugs in table one may be used as supportive care to help the patients.

\section{Funding}

Not Applicable.

\section{Availability of data and materials}

Not Applicable.

\section{Authors 'contributions}

MU: Conceptualization and writing of review manuscript.

\section{Ethics approval and consent to participate}

Not Applicable. 


\section{Consent for publication}

The article and the sources used have been cited in the article.

\section{Competing interests}

The author declare that he has no competing interests.

\section{References:}

1. Novel CPERE. The epidemiological characteristics of an outbreak of 2019 novel coronavirus diseases (COVID-19) in China. Zhonghua liu xing bing xue za zhi= Zhonghua liuxingbingxue zazhi. 2020;41(2):145.

2. Brian D, Baric R. Coronavirus genome structure and replication. In: Coronavirus replication and reverse genetics. Springer; 2005:1-30.

3. Ullah M. The Pandemic of Novel Coronavirus Disease 2019 (COVID-19): Need for an Immediate Action. Open Access Journal of Biomedical Science. 2020;2(1).

4. Prompetchara E, Ketloy C, Palaga T. Immune responses in COVID-19 and potential vaccines: Lessons learned from SARS and MERS epidemic. Asian Pac J Allergy Immunol. 2020;38(1):1-9.

5. Sohrabi C, Alsafi Z, O'Neill N, et al. World Health Organization declares global emergency: A review of the 2019 novel coronavirus (COVID-19). Int J Surg. 2020;76:71-76.

6. Ullah M. Need For Specialized Therapeutic Stem Cells Banks Equipped With Tumor Regression Enzymes And Anti-Tumor Genes. J BiomedAllied Res. 2020;2(1):1-6.

7. Zhang L, Liu Y. Potential interventions for novel coronavirus in China: A systematic review. J Med Virol. 2020;92(5):479-490.

8. Walls AC, Park YJ, Tortorici MA, Wall A, McGuire AT, Veesler D. Structure, Function, and Antigenicity of the SARS-CoV-2 Spike Glycoprotein. Cell. 2020.

9. Wu A, Peng Y, Huang B, et al. Genome Composition and Divergence of the Novel Coronavirus (2019-nCoV) Originating in China. Cell Host Microbe. 2020;27(3):325-328.

10. Xu Z, Shi L, Wang Y, et al. Pathological findings of COVID-19 associated with acute respiratory distress syndrome. Lancet Respir Med. 2020.

11. Chen H, Guo J, Wang C, et al. Clinical characteristics and intrauterine vertical transmission potential of COVID-19 infection in nine pregnant women: a retrospective review of medical records. Lancet. 2020;395(10226):809-815.

12. Lu H. Drug treatment options for the 2019-new coronavirus (2019-nCoV). Biosci Trends. 2020;14(1):69-71.

13. Ullah M, Akbar A, Yannarelli G. Applications of artificial intelligence in, early detection of cancer, clinical diagnosis and personalized medicine. Artificial Intelligence in Cancer. 2020;1(2):39-44.

14. Ullah M AA. Clinical Relevance of RNA Editing to Early Detection of Cancer in Human. Int J Stem Cell Res Ther 2020;7:066. .

15. Ullah M, Qiao Y, Concepcion W, Thakor AS. Stem cell-derived extracellular vesicles: role in oncogenic processes, bioengineering potential, and technical challenges. Stem Cell Res Ther. 2019;10(1):347. 
16. Ullah M. Novel Coronavirus (COVID-19) Treatment Options. Biomed J Sci \& Tech Res (BJSTR).27(3):20872-20874.

17. Gao J, Tian Z, Yang X. Breakthrough: Chloroquine phosphate has shown apparent efficacy in treatment of COVID-19 associated pneumonia in clinical studies. Bioscience trends. 2020.

18. Law PK. Emergent Serum Therapy and Antibody Medicine to Counteract Sudden Attacks of COVID19 and Other Pathogenic Epidemics. In: Scientific Research Publishing; 2020.

19. Dyall J, Coleman CM, Hart BJ, et al. Repurposing of clinically developed drugs for treatment of Middle East respiratory syndrome coronavirus infection. Antimicrob Agents Chemother. 2014;58(8):4885-4893.

Table: 1

\begin{tabular}{|c|c|c|}
\hline Drugs/Compounds & Mechanism of Action & Classification \\
\hline $\begin{array}{l}\text { Favipiravir/Galidesivir/ } \\
\text { Remdesivir }\end{array}$ & $\begin{array}{l}\text { Potently inhibits the RNA- } \\
\text { dependent RNA polymerase }\end{array}$ & Antiviral \\
\hline Epetraborole hydrochloride & Inhibits growth & Antibacterial \\
\hline Saquinavir/ Nelfinavir & Protease inhibitor & Antiviral \\
\hline Carfilzomib & Proteasome inhibitor & Antiviral \\
\hline Zanamivir & Neuraminidase inhibitor & Antiviral \\
\hline Ribavirin & $\begin{array}{l}\text { Broad spectrum antiviral } \\
\text { agent }\end{array}$ & Antiviral \\
\hline Bimosiamose & $\begin{array}{l}\text { Inhibitor of S protein and } \\
\text { ACE2 }\end{array}$ & Antiviral, Anti-inflammatory \\
\hline Chloroquine & Anti-malarial drug & An antimalarial agent \\
\hline Actemra & $\begin{array}{l}\text { Inhibits the RNA-dependent } \\
\text { RNA polymerase }\end{array}$ & Antiviral, Anti-inflammatory \\
\hline $\begin{array}{l}\text { TJM2/AT-100/TZLS- } \\
\text { 501/BPI-002/INO-4800 }\end{array}$ & $\begin{array}{l}\text { Neutralizing antibody, inhibit } \\
\text { virus, vaccine }\end{array}$ & $\begin{array}{l}\text { Antibody, Anti-inflammatory, } \\
\text { Recombinant proteins }\end{array}$ \\
\hline
\end{tabular}

Table-1: Here is a list of the major coronavirus drugs that have the potential to become major coronavirus vaccines or antivirals for treating the coronavirus infection. 


\section{COVID-19 VIRUS}

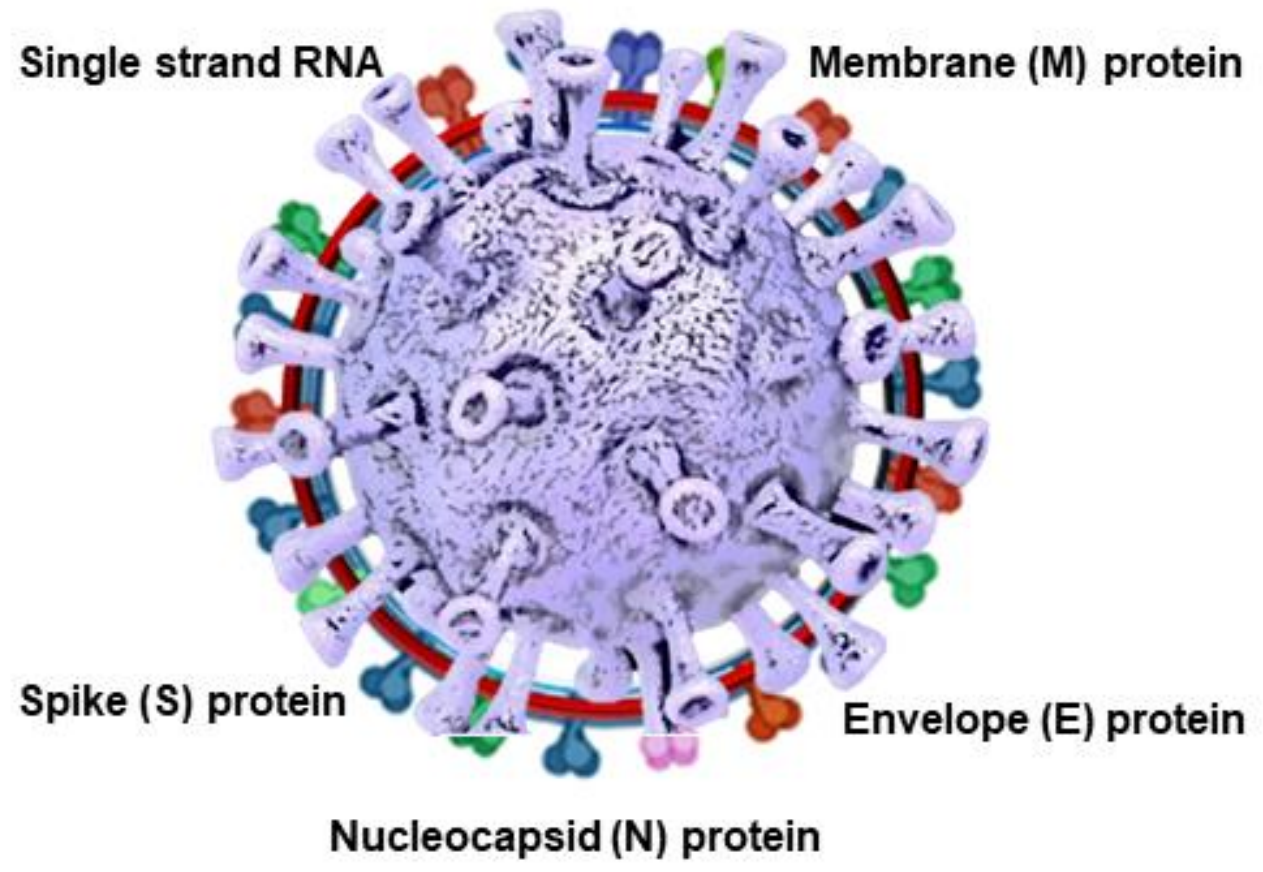

Figure-1.

Illustration of COVID-19 VIRUS. 